\title{
Do river discharge rates drive the overall functioning of the pelagic ecosystem over the continental shelf of the Bay of Biscay (NE Atlantic)? A comparison of two contrasting years with special reference to anchovy (Engraulis encrasicolus L.) nutritional state
}

\author{
Jean-Pierre Bergeron ${ }^{1,{ }^{*}}$, Daniel Delmas ${ }^{2}$, Noussithé Koueta $^{3}$
}

\author{
${ }^{1}$ IFREMER, Centre Atlantique, Département Écologie et Modèles pour l'Halieutique (EMH), B.P. 21105 , F-44311 \\ NANTES CEDEX 03, France \\ 2 IFREMER, Centre Bretagne, Département Dynamique de l'Environnement Côtier (DYNECO), B.P. 70, F-29280, \\ PLOUZANE, France \\ ${ }^{3}$ Université de Caen, Laboratoire de Biologie et Biotechnologies Marines, Esplanade de la Paix, F-14032 CAEN \\ CEDEX, France
}

*: Corresponding author : J.-P. Bergeron, email address : jean.pierre.bergeron@ifremer.fr

\begin{abstract}
:
In the 2000 and 2001 springtime periods, mesozooplankton samples were systematically taken during research cruises devoted to the study of the distribution and abundance of small pelagic fishes in the French part of the Bay of Biscay, NE Atlantic, continental shelf. Simultaneous activities of three enzymes were measured in these mesozooplankton samples, to characterize the main features of ecosystem function at a regional scale. The aim was to assess assimilation rates of carbohydrates, through pyruvate kinase activity, and protein, through trypsin activity, by the mesozooplankton community and the resulting overall productivity, through aspartate transcarbamylase activity. The highest influence on the pelagic environment was the strong difference in the freshwater outflow rates from the two main large rivers, the Loire and the Gironde, which was principally responsible for the inter-annual fluctuations of the nutrients in the Bay. This overall influence of river flow results in a characteristic pattern of sea-surface salinity, which was reflected by the phytoplankton biomass distribution. Mesozooplankton enzyme activities showed high variations between the two years. The contrast in the dynamics of the pelagic food web processes between the two consecutive years, with higher activity in 2001, affected the nutritional condition of the zooplanktivorous breeding anchovy Engraulis encrasicolus.
\end{abstract}

Keywords: rivers discharge, phytoplankton distribution, anchovy, nutritional state, RNA/DNA ratio, mesozooplankton, metabolic descriptors, North-East Atlantic, Bay of Biscay. 
In the Bay of Biscay, a temperate region of the North Atlantic $\left(44 \sim 48{ }^{\circ} \mathrm{N}\right)$, the anchovy population constitutes important fish resources shared by Spanish and French fishing fleets. Unlike most other small pelagic fish populations all over the world, the anchovy in the Bay of Biscay is not dependent on a large physical enrichment process comparable to eastern boundary up-welling regions such as the Humbolt, Benguela, California, Canaries currents. Generally we lack information about what are the effective recruitment areas for anchovies in non-upwelling regions. On the other hand, there is strong circumstantial evidence worldwide that nutrient enriched riverine discharge enhances fishery production on adjacent continental shelves (e.g., for the Mississippi River, Grimes, 2001), and this appears to be the case in the Bay of Biscay (Motos et al., 1996) into which two very large rivers flow, the Gironde, around $45^{\circ} 30 \mathrm{~N}$, and the Loire, slightly more to the north.

During fisheries research cruises devoted to small pelagic fishes in the Bay of Biscay, mesozooplankton samples are systematically taken for measurements of enzyme activities (Petitgas et al., 2006; Bergeron et al., 2009) with the aim of characterizing the main features of the pelagic ecosystem functioning at the mesoscale. The Bay of Biscay region is subject to various strong physical driving forces (Bergeron, 2004): among these, two are permanent but vary in their effects according to seasonal conditions. First, as mentioned above, two large rivers, the Loire and the Gironde, debouch into the middlenorthern part of the region. There is also a smaller river in the south, the Adour, which is generally at its outflow maximum during the breeding season (around May) of the anchovy population; this is water issuing from the spring thaw of snow in the nearby Pyrenees Mountains. Secondly, another source of nutrients exists over the shelf break, the upwelling of deep waters (highest surface salinity for the region, 35.6) induced by strong tidally induced internal waves, but this process is much less variable at the inter-annual scale. Therefore, these two processes exert opposing influences on the surface layer because one brings freshwater, the other carries high salinity waters (Bergeron, 2004).

These physical processes directly affect the primary structure of the pelagic food web. The mesozooplankton community constitutes the first level of integration of hydro-climatic forcing in the pelagic food web; this offers a powerful tool that can be profitably exploited in the characterization of the basic processes on which the system rests. Such forcings primarily affect the metabolism of individuals and lead to overall changes in the functioning of the community. In attempts to assess the main features of this overall functioning, the use of biochemical tools, more specifically the measurement of enzymatic activities in samples of the mesozooplankton community, has been advocated (Bergeron $1983,1986,1995)$. Such methods may be considered as disputable by certain authors (Berges et al., 1993), but the interest in their implementation endures because they provide the fastest, simplest, and least expensive ways to assess mesoscale variations in important metabolic features (Packard et al., 1996). Moreover, a most important aspect must be added: they are compatible with the constraints imposed by the implementation of fisheries research cruises, which must be generally performed over broad areas as quickly as possible in order to try to obtain a synoptic view of the marine system under study.

The activity of the digestive endopeptidase trypsin was selected to characterize the assimilation rate of proteins by mesozooplankton, whereas pyruvate kinase (PK) was chosen as an indicator of carbohydrate assimilation and aspartate transcarbamylase (ATC) provided an overall assessment of mesozooplankton productivity. Moreover, the nutritional state of breeding anchovy Engraulis encrasicolus was estimated through variations of a biochemical index: it is the RNA/DNA ratio determined in their white muscle. Hydrobiological conditions in 2000 and 2001 were strongly contrasting owing to quite different outflow rates of the two large rivers. Resulting from these hydrobiological conditions, we present here 1) the consequences on the main features of the pelagic ecosystem, 2) the effects on the metabolism of the mesozooplankton community, and 3) the nutritional state of adult anchovy during the breeding seasons of 
both years. Good nutrition is of particular importance for a multiple spawner such as anchovy, notably because metabolic energy supplied by nutrition is crucial to maintain the continuous process of the de novo vitellogenesis during the whole breeding season (Hunter and Leong (1981) for the "northern anchovy" Engraulis mordax; Motos (1996) for E. encrasicolus of the Bay of Biscay).

\section{Material and methods}

The PEL2000 research cruise occurred from April 17 to May 13, 2000; the following cruise, PEL2001, from April 27 to June 5, 2001; both were aboard the RV Thalassa. The cruises, which were also devoted to the study of the abundance and spatial distribution of small pelagic fishes using acoustic tools (Scalabrin and Massé, 1993), covered the entire French part of the continental shelf of the Bay of Biscay (i.e., a little more than $4^{\circ}$ in latitude). Mesozooplankton sampling occurred at stations located along transects that ran roughly perpendicular to the coastline: 69 mesozooplankton samples were collected during each of these cruises (Fig. 1). It should be also noted (we will have to consider this point below) that the sampling season at each cruise was slightly different, that is, the end of sampling in 2001 (4 June) occurred roughly one month later than the end of sampling of the Bay in 2000 (1 May, end of the first leg).

\subsection{Hydrobiology}

Surface salinity was obtained from the conductivity probe of the vessel, which also allowed sampling of surface water with high frequency in order to obtain a description of the hydrological environment (salinity, nitrate, $\mathrm{Chl} \mathrm{a)} \mathrm{as} \mathrm{precisely} \mathrm{and} \mathrm{detailed} \mathrm{as} \mathrm{possible.}$ Furthermore, on each station, water samples were taken at five depths for measurements of nutrients, the samples were filtered on glass fibre filters (Whatman GF/F, pore size 0.7 $\mu \mathrm{m})$ with a syringe filtration system. Samples were stored in polyethylene flasks, frozen $\left(-25^{\circ} \mathrm{C}\right)$ and analysed later in the laboratory according to the classical methods described by Strickland and Parsons (1972). Nitrate was selected as the most representative nutrient presumably linked to surface salinity variations. Total chlorophyll a (Chl a) was determined by filtration of seawater samples through Whatman GF/F filters. Filters were frozen and analyzed later by the fluorometric acidification procedure in $100 \%$ methanol extracts (Holm-Hansen et al., 1965, modified by Holm-Hansen and Riemann, 1978)

\subsection{Mesozooplankton samples}

The methodology applied to mesozooplankton samples followed Petitgas et al. (2006). Samples were collected with a classical WP2 net (Unesco, 1968), i.e. $0.25 \mathrm{~m}^{2}$ mouth opening, $0.2 \mu \mathrm{m}$ mesh size, hauled up from $5 \mathrm{~m}$ over the bottom (or $200 \mathrm{~m}$ depth when the depth was greater, i.e. beyond the continental slope) to the surface. The bulk of mesozooplankton consists of copepods making up as much as $80 \%$ of the biomass, and often even more as described by Williams et al. (1994) for the European shelf seas and confirmed by a study by Plounevez and Champalbert (1999), i.e. 92 98\% specifically in the Bay of Biscay. Zooplankton homogenates were immediately processed after the collection of the sample and then stored in liquid nitrogen until analysis, as this storage procedure does not introduce any significant change in enzymatic activities (Biegala and Bergeron, 1998).

Trypsin activity was estimated by the classical "BAPNA method" (BAPNA: N-benzoyl-Larginine-p-nitroanilide, following Erlanger et al., 1961). The BAPNA synthetic substrate is specifically hydrolyzed by trypsin with the production of paranitroaniline ( $p N A)$ which absorbs at $405 \mathrm{~nm}$. This method was adapted to zooplankton extracts by Samain et al. 
(1977). Pyruvate kinase (PK) activity was assessed according to Bücher and Pfleiderer (1955), later modified by Bergeron and Herbland (2001). The method for ATC activity as initially described by Bergeron and Alayse-Danet (1981) and revised by Biegala and Bergeron (1998).

Trypsin specific activity is expressed in $\mu \mathrm{M}$ pNA (paranitroaniline) released $\mathrm{min}^{-1} \mathrm{mg}^{-1}$ protein. The unit for PK specific activity is in $\mu \mathrm{M} \mathrm{NADH}$ oxidized $\mathrm{min}^{-1} \mathrm{mg}^{-1}$ protein, and for ATC specific activity is in nM CA (carbamylaspartate) produced $\mathrm{min}^{-1} \mathrm{mg}^{-1}$ protein.

\subsection{Anchovy sampling and sample processing}

Small pelagic fish shoals were tracked along transects at a vessel speed of 9 knots with a calibrated OSSIAN 1500 split beam echo sounder (frequency: $38 \mathrm{kHz}$ ). Identification of species in the echo traces was conducted by fishing with a 76/70 pelagic trawl with a $20 \mathrm{~m}$ vertical opening and a $10 \mathrm{~mm}$ mesh cod end. Sampling anchovies was made by picking up from the catch a fixed number (15 in the present study) of individuals: this was made at random, but damaged individuals were discarded. A total of 615 individuals $(18 \times 15$ in 2000 and $23 \times 15$ in 2001) were collected from the trawls. A small sample of the white trunk muscle was cut out of the dorsal part of the body, between the middle of the back headfront dorsal fin point and the back dorsal fin point. The size of the sub-sample generally varied with the size of the individual, i.e. from 0.5 to $1.6 \mathrm{~g}$ fresh weight for individual length between 120 and $170 \mathrm{~mm}$. Each sub-sample was introduced into a cryovial, immediately frozen at $-40^{\circ} \mathrm{C}$ and kept at this temperature until analysis in the laboratory.

\subsection{RNA/DNA determination}

After thawing in the laboratory, the small pieces of white trunk muscle were ground with a Polytron in varying volumes $(\mathrm{V}$ in $\mathrm{ml})$ of ice-cold distilled water $\left(4^{\circ} \mathrm{C}\right)$, which were adjusted relative to their fresh weight ( $F W$ in $g$ ), i.e. $V=50 \times F W$, with the aim of optimizing the range of nucleic acid values and so increasing the accuracy of estimates. Then, a subsample of this homogenate was taken and subjected again to a second homogenization $\left(4^{\circ} \mathrm{C}\right)$ with a Potter-Elvehjem, which eliminates the smallest particles that may prevent stable fluorescence measurements. This sample was immediately processed, in triplicates, for nucleic acid determination by the fluorimetric method initially suggested by Le Pecq and Paoletti (1966), modified according to Karsten and Wollenberger $(1972,1977)$ and in the conditions tested and defined by Bergeron and Boulhic (1994). Type I DNA $\left(\right.$ Sigma $\left.^{\circledR}\right)$ from calf thymus was used as standard (assays were made with rRNA Sigma ${ }^{\circledR}$ from calf liver as the second standard to verify the validity of the correction factor 0.46 proposed by Karsten and Wollenberger in 1972 and gave satisfactory results, therefore only DNA was used as standard for routine estimates).

It must be specified that numerous preliminary assays had been carried out on several occasions during previous cruises to detect influences of size and notably sex on the RNA/DNA ratio determination: no significant differences were found (Bergeron, unpublished data). Pelletier et al. (1995) stated that no significant relationships were observed between white muscle RNA concentration and growth rate in adult fish, which is in agreement with an overall analysis by Bergeron (1997) who suggested that RNA concentration may be related to growth rate only if growth is dependent on feeding conditions. In a review about the use of nucleic acids estimates in ichthyoplankton ecology, Bergeron (1997) emphasized the importance of cellular processes originating the regulation of RNA content in fish white muscle: the number of ribosomes (85 90\% of total cellular RNA) are closely linked to feeding conditions. This explains why, in studies devoted to juvenile fish most often following larvae rearing experiments (Richard et al., 1991), the preponderance of muscular mass in juvenile stages plays a major role in 
determining the RNA/DNA ratio level in homogenates of whole individuals. This permits, from such studies (Gwak and Tanaka, 2001), to define the levels of the ratio in well-fed juvenile fish, which is reinforced by results of RNA/DNA determination carried out specifically in samples of white muscle isolated from the fish carcass (Miglavs and Jobling, 1989). Consequently, from an overall examination of the literature, one may conclude that it is generally agreed that the threshold of 2 is the lower limit for the RNA/DNA ratio under which individuals are graded in poor condition (Miglavs and Jobling, 1989; Gwak and Tanaka, 2001). For testing differences between years, a Pearson's chisquared test (Chernoff and Lehmann, 1954) was used for comparing the distributions of individual nutritional states.

\section{Results}

\subsection{Hydrobiological environment}

For both years considered here, the interannual variability of outflow rates from the two large rivers is high (Fig. 2): in 2001 the maximum outflow rate was nearly twice the levels recorded in 2000, the amount of freshwater flow is so high that it has invaded almost the whole surface layer of the Bay. In 2000, the influx of nutrient-enriched freshwater is clearly indicated by the low salinity of surface waters along the coast (Fig. 3), which is in agreement with the classical residual circulation in this part of the Bay described by Koutsikopoulos and Le Cann (1996) and reinforced by south-westerly winds (MétéoFrance data from the Chassiron semaphore: cf. location in Fig. 1). In 2001, nuclei of less saline water were found in front of the mouths of rivers and moved away from the coast under the effect of north-westerly winds (P. Lazure, IFREMER, Dept. DYNECO, pers. comm.). Lastly, a strong contrast between both years is revealed in examining the surface salinities recorded along the shelf break. The average sea surface salinity is significantly (Student's $t$ test: $t=3.91 / \alpha<0.01$ ) higher in 2000 (mean for 7 points over the continental slope: 35.59 , S.D. 0.03 , i.e. very close to that of deep waters, which is worth 35.60) than in 2001 (mean value for the same points: 35.28, S.D. 0.22). This indicates that in 2001 nutrient supply by up-welled deep water along the continental slope is less influential in comparison with that provided by river outflows along the coast of the Bay. Surface nutrient values in terms of nitrate show strong differences (Fig.4). The spatial distribution conforms to different outflow rates of rivers, notably with a larger extent in 2001, although surface concentrations appear lower than in 2000, as shown by the classical dilution line describing the nutrient concentration vs salinity relationship (Fig. 5). Surface chlorophyll a concentrations varied according to the potential enrichment in nutrients, both at interannual (overall between 2000 and 2001) and spatial scales, i.e. associated with patches of less saline coastal water, especially in 2001 (Fig. 6).

\subsection{Mesozooplankton enzymatic indices}

The values of trypsin specific activities were very contrasting in the two years (Fig. 7). In 2000 they were relatively high: three highest values (distinctly over six) were either along the coast in the plume of desalted water flowing out of the Gironde estuary or near the shelf break in the north; the whole of the other values were divided into two approximately equivalent groups ranging either between 2 and 4, or between 4 and 6. In 2001 they were weak in general, below 4, except in front of the two large estuaries where there were two groups of highest values above 6 , even far beyond, i.e. mean values $=9.07$ (S.D. 1.48) and 18.11 (S.D. 12.26) for three stations located in front of the Loire and the Gironde respectively. These nuclei of highest trypsin activity coincide with nuclei of lowest salinity that are potentially the richest in nutrients. An increase of PK activity was observed over the major portion of the Bay, overall PK activities were higher in 2001 (Fig. 8). The overall 
productivity of mesozooplankton is indicated by ATC specific activities. A distinct pattern appeared between the two years (Fig. 9). In 2001, the highest values were mainly found in the southern part of the shelf.

\subsection{Anchovy nutritional condition}

The contrasting environmental conditions have notable consequences on the nutritional state of anchovy (Fig. 10). In 2000, only six trawled samples out of 18 displayed an adequate nutritional condition (ratio $>2$ ), whereas in 2001, four samples out of 23 were in poor condition when all others were in good or even excellent (ratio $>3$ ) condition.

\section{Discussion}

A key finding of this research is the magnitude of the difference between metabolic descriptor levels in the mesozooplankton community between 2000 and 2001 . Owing to strong differences in the outflow rates of rivers and, consequently, the influence of different enrichment in nutrients, the two years presented different features at the primary levels of the pelagic food web. At the origin of the trophic cascade, the dissolved inorganic nitrogen content of upstream freshwater, i.e. at nil salinity, of the Loire and Gironde rivers remains unchanged whatever the river flow, at least when it is over $10^{3} \mathrm{~m}^{3} \cdot \mathrm{sec}^{-1}$ (Guillaud et al., 2008), which was the case for the two years considered here. Therefore, the large extent of sea surface low salinity in 2001 is in accordance with a higher inflow into the Bay in comparison with 2000. Large differences in nitrate concentration for a given salinity indicate that in 2001 the consumption of this nutrient by photosynthetic cells is significantly higher than in 2000.

This is notably illustrated through the trypsin specific activities, which in 2001 showed low levels $(<4)$ almost all over the whole study area, except on two nuclei of a few stations located in front of the large estuaries where strongly higher values $(>6)$ contrasted. A simple explanation for high trypsin activity found in these restricted places of lowest salinity and potentially richest in nutrients is that rapidly growing phytoplankton cells are very rich in proteins (Granum et al., 2002). When nutrients become less abundant, their content in carbohydrates increases (ibid.), which is often revealed by an increase of PK activity. This was observed over the major portion of the Bay: overall PK activities were higher in 2001.

The high values of the metabolic descriptors, principally PK and ATC, do not appear consistent to the features observed in the primary levels. As mentioned previously, there is a lag of the seasonal cycle at which the sampling was carried out between the two years. The southern half of the Bay, where the highest ATC activities were recorded, has been covered one month later in 2001 (late May) than in 2000 (late April). Consequently, the daily duration of sunshine was longer, and its intensity higher, in 2001 than in 2000. Therefore, it is probable that primary production in 2001 was higher than that in 2000, which would explain the lower values of nitrate observed for 2001 in the surface nitrate/salinity relationship: it is mostly the effect of a more important uptake of nutrients by an actively growing phytoplankton community. In fact, a slightly higher phytoplankton biomass can be observed in 2001, mainly in the river plumes. However, this increase - in comparison with the biomass found in 2000 - is moderate. Furthermore, this is a static view of a dynamic process as the pelagic environment is regularly supplied with high amounts of nutrients by the rivers' outflow. The enhanced primary productivity may be affected by high levels of grazing by the mesozooplankton community, which would result in strong PK activities. A similar reasoning had led to justify a direct link between PK activity and nitrate availability in conditions of very low nutrient enrichment (Bergeron, 2006). Within such a context, high ATC specific activities measured in 2001 would reveal the resultant effect of enhanced primary productivity and mesozooplankton grazing. Such 
results emphasize yet again that estimates of metabolic processes, through enzyme activities measured in mesozooplankton, as suggested by Bergeron et al. (2009), permit the collection of invaluable information about the dynamics of pelagic food webs, the habitat of anchovy. The gap in the dynamics of the pelagic food web processes between the two consecutive years measured here has repercussions for the nutritional condition, better in 2001 than in 2000, of the zooplanktivorous breeding anchovies.

According to Blaxter and Hunter (1982), the selection of specific spawning sites in clupeoids is related to good feeding conditions for adults, which is confirmed by Motos et al. (1996) for the Bay of Biscay anchovy. Such conditions in the Bay of Biscay are driven by different physical processes responsible for local enrichments in basic nutrients (Koutsikopoulos and Le Cann, 1996; Bergeron, 2004), and are therefore also responsible for a year to year pattern of the spawning anchovy spatial distribution (Motos et al., 1996). Strong yearly quantitative differences may exist in processes occurring in these spawning sites, such as varying outflow rates of nutrient-rich freshwater from large estuaries debouching into the Bay of Biscay.

While the timing of the cruise surveys may have influenced the results, these data indicate that the input of nutrients because of increased river flow enhanced primary and secondary production and also enhanced anchovy nutrition in the Bay of Biscay. Despite differences in nutrient load between Loire and Gironde, well established as a general pattern (mean values recorded over the 1985 2003 period: 283 and $176 \mu \mathrm{M}$ in nitrate at nil salinity in Loire and Gironde respectively, data from the RNO, 2003) and recently put forward by Bergeron et al. (2009), the overall functioning of the Bay of Biscay pelagic ecosystem is strongly dependent on the discharge rates of the rivers. It is highly likely this is similar to many coastal areas around the world, with similar effects on the nutritional condition of small pelagic fishes and potential consequences on the fecundity of the multiple spawners. The fecundity of individuals of such populations is linked to varying production of gametes, the abundance of which plays a role in the recruitment of the population. It is even the first step in the numerous successive processes which will finally determine the recruitment. Recruitment still remains a recurrent question for fisheries scientists (e.g. Borja et al., 2008), but individual fecundity has long been mainly estimated with the aim of applying the famous DEPM (Daily Egg Production Method) devoted to estimates of fish abundance through spawning biomass (Stratoudakis et al., 2006). Nevertheless fecundity and nutritional condition of a multiple spawner are certainly closely linked, as suggested by Blaxter and Hunter (1982), and this study has demonstrated the prominent role of the mesozooplankton community in reflecting the overall environmental functioning through its metabolic descriptors.

\section{Acknowledgements}

The authors are greatly indebted to several colleagues of the EMH Department: Paul Bourriau and Daniel Halgand for their help in field sampling and sample processing; Nathalie Schreiber for carrying out biochemical analyses; Verena Trenkel for her help in statistics. Fruitful suggestions from two anonymous reviewers permitted substantial improvements to our article, which is warmly acknowledged. Thanks are due to Jacques Massé, manager of the IFREMER Project "Ecologie des Petits Pélagiques", and to the captain, officers, and crew of the RV Thalassa. This study was conducted within the framework of the FOREVAR Project, a French contribution to the GLOBEC (SPACC) International Programme. It was also carried out with the financial support of the French "Programme National d'Ecologie Côtière"/atelier Gascogne (PNEC-Gascogne), and the fisheries research part of the survey was partially financed by the European Commission, DG XIV, under the research project PELASSES n99/010. 


\section{References}

Bergeron, J.-P. (1983): Approche systémique des potentialités de production secondaire pélagique: l'évolution printanière en province néritique. Oceanol. Acta, (Vol. Spé. 4), 1519.

Bergeron, J.-P.(1986): Approche systémique des potentialités de production secondaire pélagique: inférences de fluctuations interannuelles. Oceanol. Acta, 9, 291-303.

Bergeron, J.-P. (1995): Aspartate transcarbamylase activity for the assessment of mesozooplankton production: new aspects from oceanic areas. ICES J Mar. Sci., 52, 305313.

Bergeron, J.-P. (1997): Nucleic acids in ichthyoplankton ecology: a review, with emphasis on recent advances for new perspectives. J. Fish Biol., 51 (Suppl. A), 284-302.

Bergeron, J.-P. (2004): Contrasting years in the Gironde estuary (Bay of Biscay, NE Atlantic) springtime outflow and consequences for zooplankton pyruvate kinase activity and the nutritional condition of anchovy larvae: an early view. ICES J Mar. Sci., 61, 928932.

Bergeron, J.-P. (2006): Small-scale variability of zooplankton pyruvate kinase activity in the Gironde Estuary plume (Atlantic French Coast): A case study under unusually low freshwater discharge. Estuar. Coast. Shelf Sci., 69, 662-666.

Bergeron, J.-P. and A.-M. Alayse-Danet (1981): Aspartate transcarbamylase de la coquille Saint-Jacques Pecten maximus L. (Mollusque Lamellibranche): méthode de dosage et variations de l'activité dans le manteau et la gonade. J. Exp. Mar. Biol. Ecol., 50, 99-117.

Bergeron, J.-P. and M. Boulhic (1994): Rapport ARN/ADN et évaluation de l'état nutritionnel et de la croissance des larves de poissons marins: un essai de mise au point expérimentale chez la sole (Solea solea L.). ICES J. Mar. Sci., 51, 181190.

Bergeron, J.-P. and A. Herbland (2001): Pyruvate kinase activity as index of carbohydrate assimilation by mesozooplankton: an early field implementation in the Bay of Biscay, NE Atlantic. J. Plankton Res., 23, 157-163.

Bergeron, J.-P., D. Delmas and N. Koueta (2009): Determining how the pelagic ecosystem over the continental shelf of the Bay of Biscay (NE Atlantic) functions: An approach using mesozooplankton enzyme activities as descriptors. Estuar. Coast. Shelf Sci., 82, 254-264.

Berges, J. A., J.C. Roff and J.S. Ballantyne (1993): Enzymatic indices of respiration and ammonia excretion: relationships to body size and food levels. J. Plankton Res., 15, 239254.

Biegala, I.C. and J.-P. Bergeron (1998): Optimal assay conditions for aspartate transcarbamylase (ATCase) activity in mesozooplankton. J. Plankton Res., 20, 12051218.

Blaxter, J.H.S. and J.R. Hunter (1982): The biology of clupeoid fishes. Adv. Mar. Biol., 20, 1-223.

Borja, A., A. Fontán, J. Sáenz and V. Valencia (2008): Climate, oceanography, and recruitment: the case of the Bay of Biscay anchovy (Engraulis encrasicolus). Fish. Oceanogr., 17, 477-493.

Bücher, T. and G. Pfleiderer (1955): Pyruvate kinase from muscle. In: Methods in Enzymology. S.P. Colowick, and N.O. Kaplan, (eds) Vol. 1. Academic Press, London, pp. 435-440.

Chernoff, H. and E.L. Lehmann (1954): The use of maximum likelihood estimates in $x^{2}$ tests for goodness of fit. Ann. Math. Stat., 25, 579-586.

Erlanger, B.F., N. Kokowsky and W. Cohen (1961): The preparation and properties of two new chromogenic substrates of trypsin. Arch. Biochem. Biopys., 95, 271-278. 
Granum, E., S. Kirkvold and S.M. Myklestad (2002): Cellular and extracellular production of carbohydrates and amino acids by the marine diatom Skeletonema costatum: diel variations and effects of $\mathrm{N}$ depletion. Mar. Ecol. Prog. Ser., 242, 83-94.

Grimes, C.B. (2001): Fishery production and the Mississippi River discharge. Fish., 26, 17-26.

Guillaud, J.-F., A. Aminot, D. Delmas, F. Gohin, M. Lunven, C. Labry and A. Herbland (2008): Seasonal variation of riverine nutrient inputs in the northern Bay of Biscay (France), and patterns of marine phytoplankton response. J. Mar. Syst., 72, 309-319.

Gwak, W.S. and N. Tanaka (2001): Developmental change in RNA:DNA ratios of fed and starved laboratory-reared Japanese flounder larvae and juveniles, and its application to assessment of nutritional condition for wild fish. J. Fish Biol., 59, 902-915.

Holm-Hansen, O. and B. Riemann (1978): Chlorophyll a determination improvements in methodology. Oikos, 30, 438-447.

Holm-Hansen, O., C. J. Lorenzen, R.W. Holmes and J.D.H. Strickland (1965): Fluorometric determination of chlorophyll. J. Cons. Int. l'Explor. Mer, 30, 3-15.

Hunter, J.R. and R. Leong (1981): The spawning energetics of female northern anchovy, Engraulis mordax. Fish. Bull., 79, 215-230.

Karsten, U. and A. Wollenberger (1972): Determination of DNA and RNA in homogenized cells and tissues by surface fluorometry. Anal. Biochem., 46, 135148.

Karsten, U. and A. Wollenberger (1977): Improvements in the ethidium bromide method for direct fluorometric estimation of DNA and RNA in cell and tissue homogenates. Anal. Biochem., 77, 464-470.

Koutsikopoulos, C. and B. Le Cann (1996): Physical processes and hydrological structures related to the Bay of Biscay anchovy. Sci. Mar., 60 (Suppl. 2), 9-19.

Le Pecq, J.B. and C. Paoletti (1966): A new fluorometric method for RNA and DNA determination. Anal. Biochem., 17, 100-107.

Miglavs, I. and M. Jobling (1989): Effects of feeding regime on food consumption, growth rates and tissue nucleic acids in juvenile Arctic charr, Salvelinus alpinus, with particular respect to compensatory growth. J. Fish Biol., 34, 947-957.

Motos, L. (1996): Reproduction biology and fecundity of the Bay of Biscay anchovy population (Engraulis encrasicolus L.). Sci. Mar., 60 (Suppl. 2), 195-207.

Motos, L., A. Uriarte and V. Valencia (1996): The spawning environment of the Bay of Biscay anchovy (Engraulis encrasicolus L.). Sci. Mar., 60 (Suppl. 2), 117140.

Packard, T.T., E. Berdalet, D. Blasco, S.O. Roy, L. St-Amand, B. Lagacé, K. Lee and J.P. Gagné (1996): Oxygen consumption in the marine bacterium Pseudomonas nautica predicted from ETS activity and bisubstrate enzyme kinetics. J. Plankton Res., 18, 18191835.

Pelletier, D., P.U. Blier, Y.Lambert and J.-D Dutil (1995): Deviation from the general relationship between RNA concentration and growth rate in fish. J. Fish Biol., 47, 920-922. Petitgas, P., J. Massé, P. Bourriau, P. Beillois, J.-P Bergeron, D. Delmas, A. Herbland, N. Koueta, J.-M. Froidefond and M. Santos (2006): Hydro-plankton characteristics and their relationship with sardine and anchovy distributions on the French shelf of the Bay of Biscay. Sci. Mar., 70 (Suppl. 1), 161-172.

Plounevez, S. and G. Champalbert (1999): Feeding behaviour and trophic environment of Engraulis encrasicolus (L.) in the Bay of Biscay. Estuar. Coast. Shelf Sci., 49, 177-191.

Richard, P., J.-P. Bergeron, M. Boulhic, R. Galois and J. Person-Le Ruyet (1991): Effect of starvation on RNA, DNA and protein content of laboratory-reared larvae and juveniles of Solea solea. Mar. Ecol. Prog. Ser., 72, 69-77.

RNO (2003):Travaux du Réseau National d'Observation de la qualité du milieu marin. Edited by IFREMER, 48 pp.

Samain, J.-F, J.-Y. Daniel and J.-R. Le Coz (1977); Trypsine, amylase et protéines du zooplancton: dosage automatique et manuel. J. Exp. Mar. Biol. Ecol., 29, 279-289. 
Strickland, J.D.H. and T.R. Parsons (1972): A practical handbook of seawater analysis. Bull. Fish. Res. Board Can., 167.

Scalabrin, C. and J. Massé (1993): Acoustic detection of the spatial and temporal distribution of fish shoals in the Bay of Biscay. Aquat. Living Resour., 6, 269-283.

Stratoudakis, Y., M. Bernal, K. Ganias and A. Uriarte (2006): The daily egg production method: recent advances, current applications and future challenges. Fish Fish., 7, 35-57. Unesco (1968): Zooplankton sampling. The Unesco Press, Paris, 174 pp.

Williams, R., D.V.P. Conway and H.G. Hunt (1994): The role of copepods in the planktonic ecosystems of mixed and stratified waters of the European shelf seas. Hydrobiol., 292/293, 521-530.

Figures 




Figure 1

Chart of the stations sampled in the Bay of Biscay. Black dots represent stations where all the operations were carried out, open symbols indicate stations where only vertical temperature and salinity profiles were recorded and mesozooplankton samples were collected. A star indicates the location of the Chassiron semaphore (about $46^{\circ} \mathrm{N}$ ). 


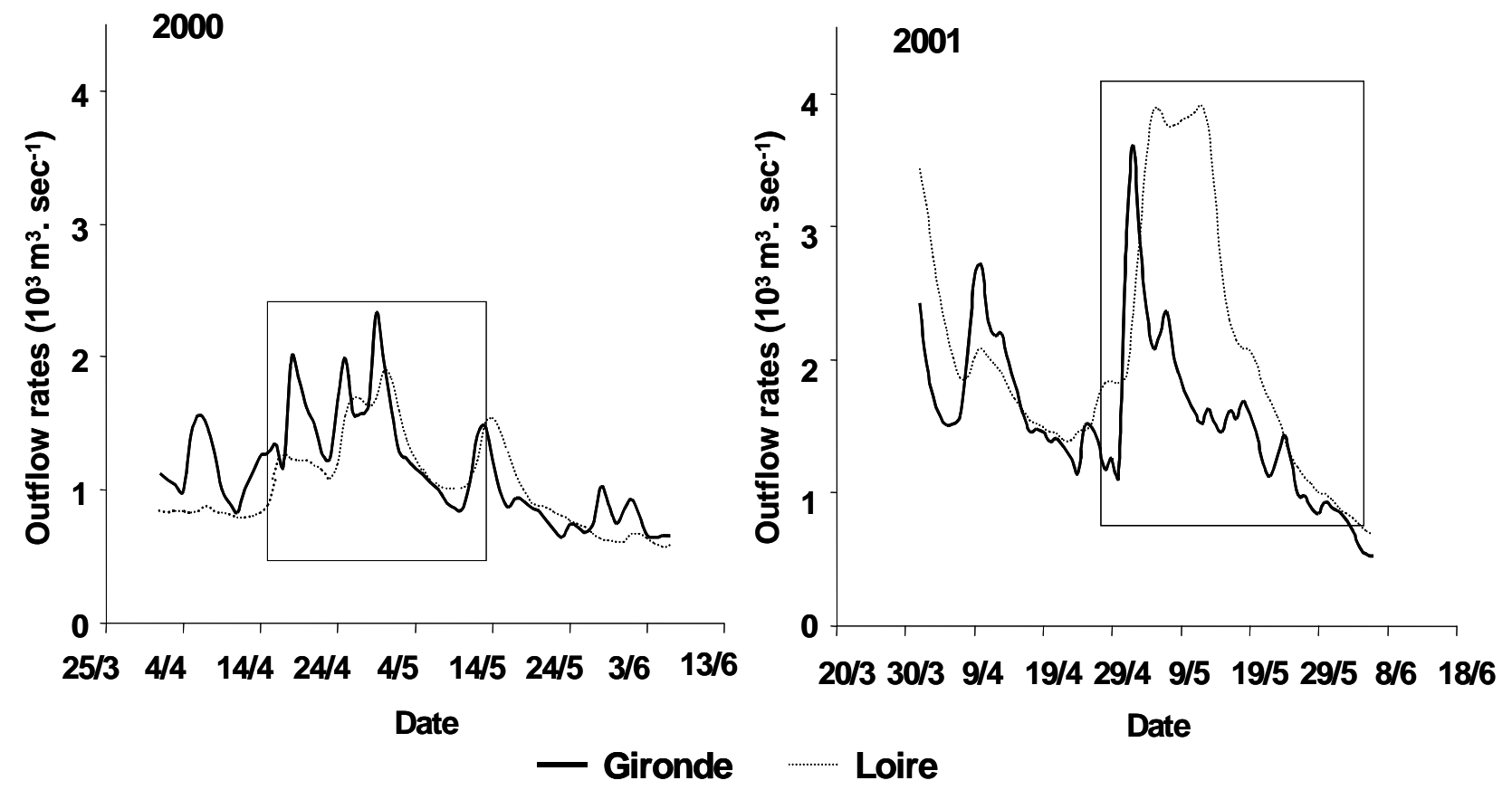

Figure 2

Outflow rates of the main large rivers on the two consecutive breeding seasons in spring 2000 and 2001. Two frames indicate the dates of sampling periods of each survey. 

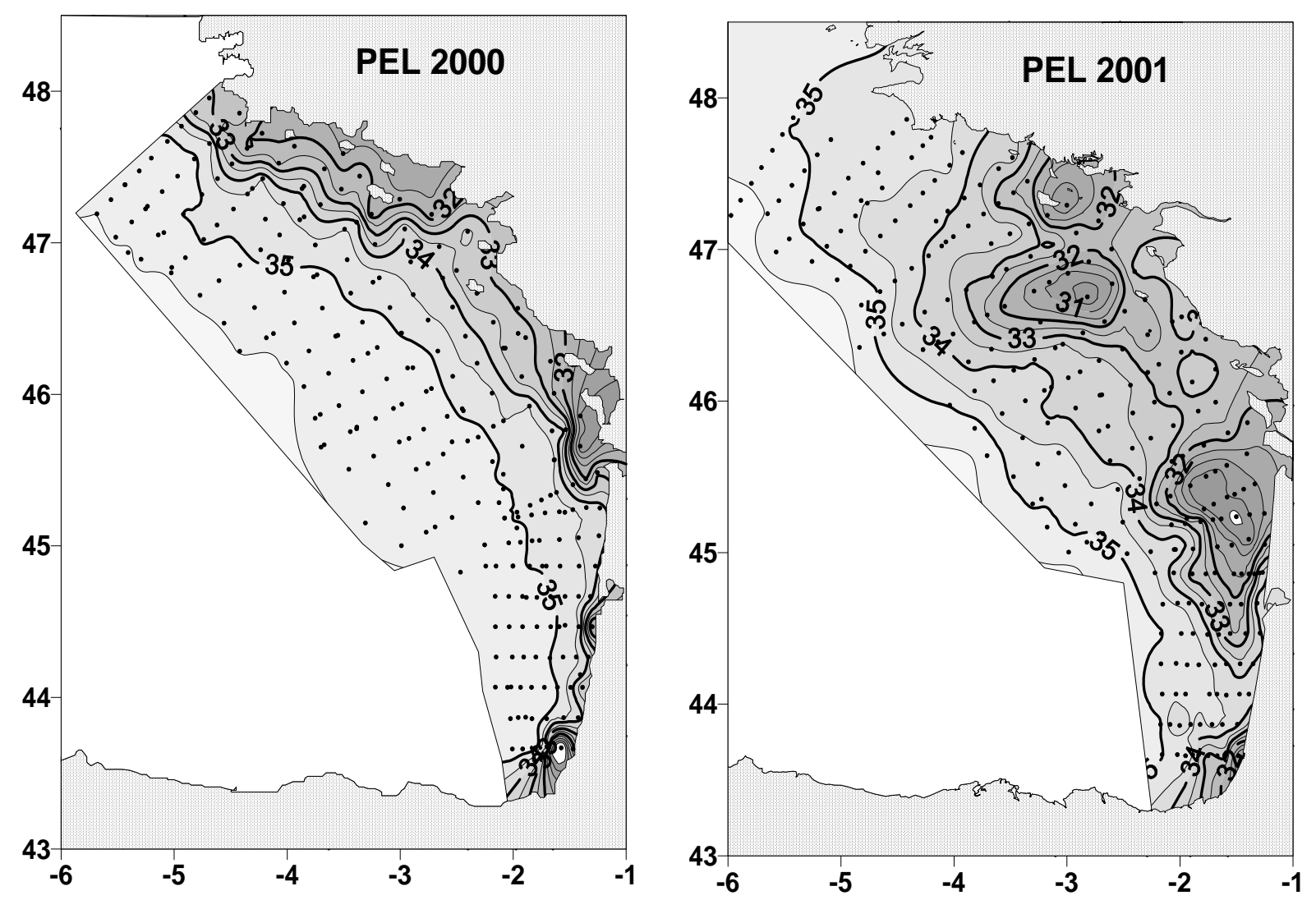

Figure 3

Spatial variation of surface water salinity within the Bay of Biscay during spring periods of 2000 and 2001. 

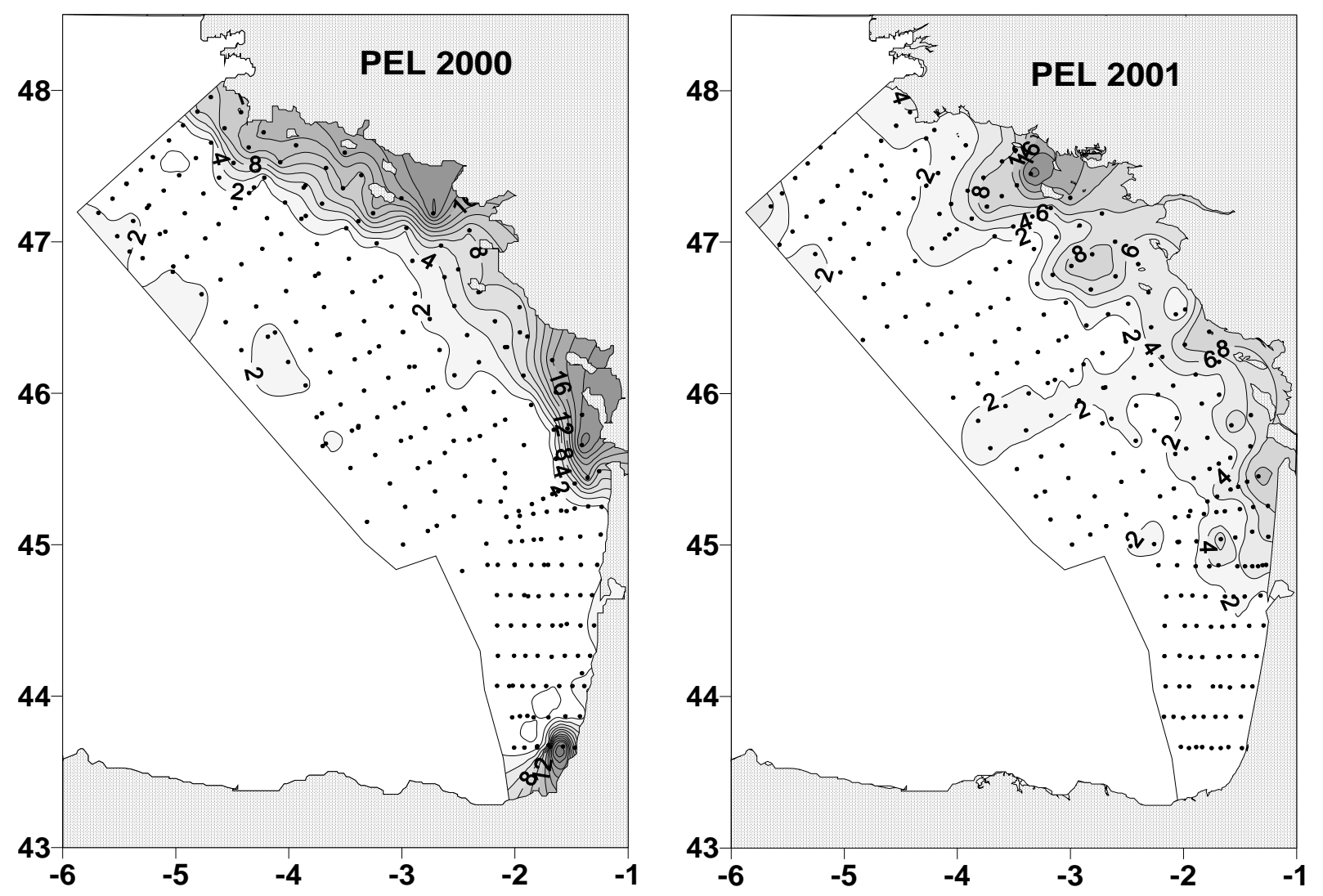

Figure 4

Spatial variation of nitrate concentration in surface waters, expressed in $\mu \mathrm{M}$, within the Bay of Biscay during spring periods of 2000 and 2001.

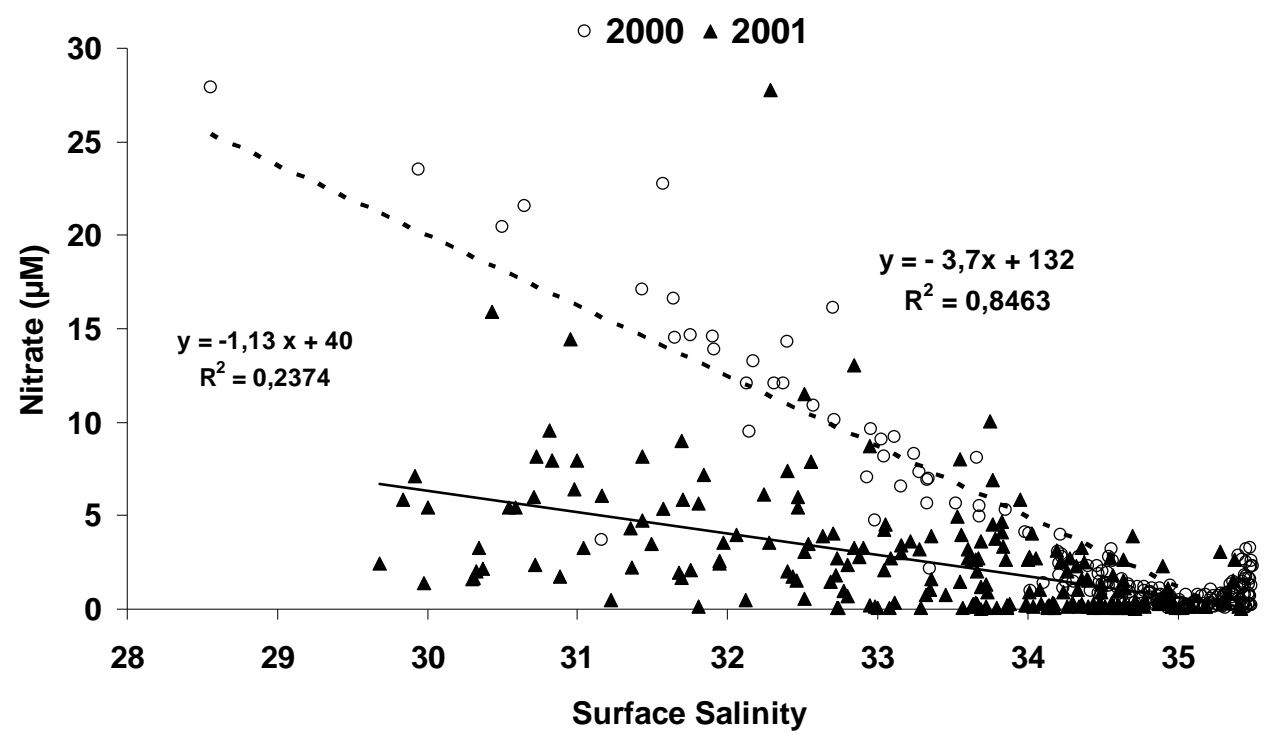

Figure 5

Surface nitrate (in $\mu \mathrm{M}$ ) vs salinity relationships during spring for both years 2000 and 2001 
within the Bay of Biscay.
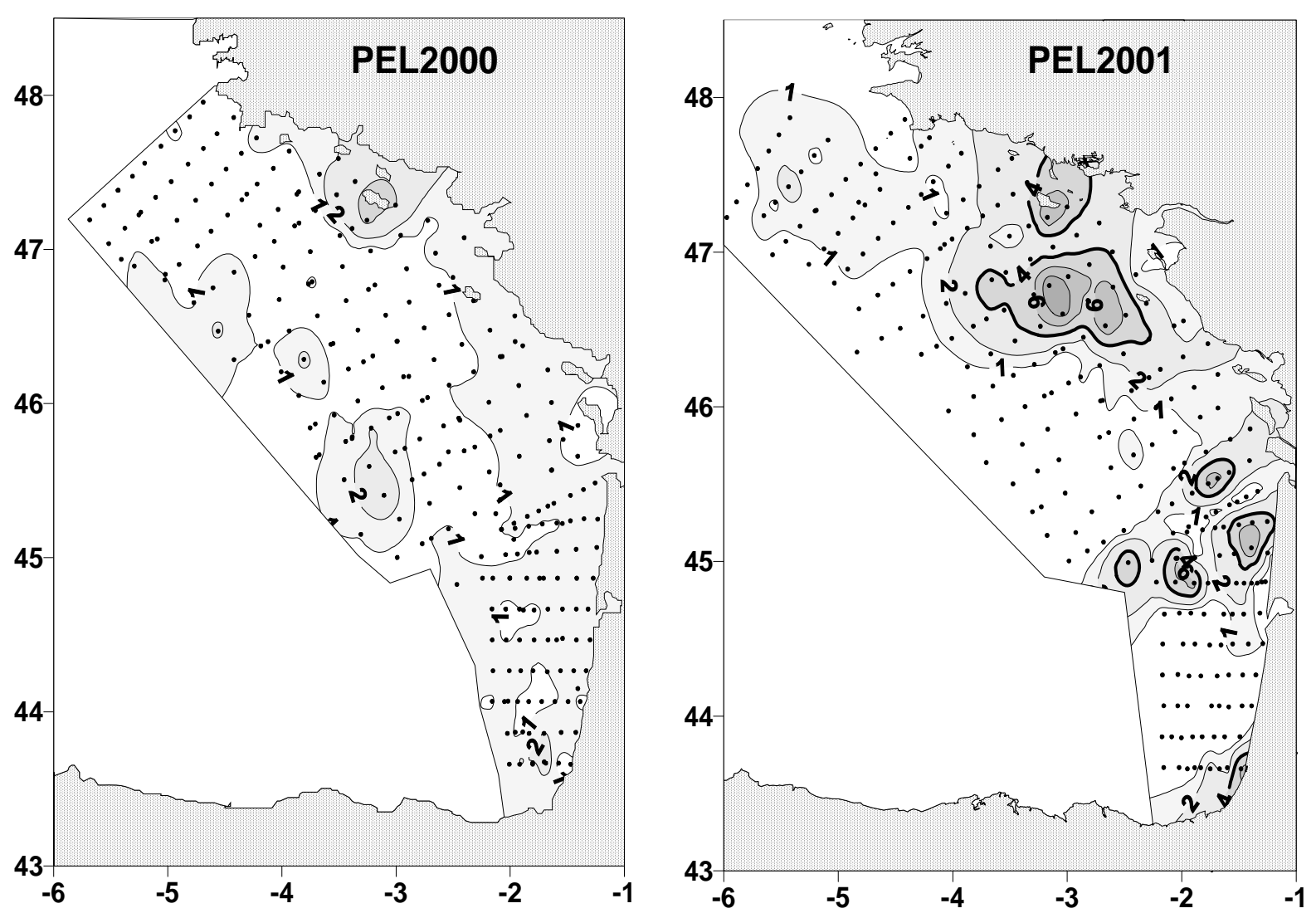

Figure 6

Surface Chl a concentrations expressed in $\mu \mathrm{g} . \mathrm{I}^{-1}$ within the Bay of Biscay during spring periods of 2000 and 2001. 



Fig.7

Spatial distributions of mesozooplankton trypsin specific activity ( $\mu \mathrm{M}$ pNA (paranitroaniline) released $\mathrm{min}^{-1} \mathrm{mg}^{-1}$ protein) within the Bay of Biscay during spring periods of 2000 and 2001. 

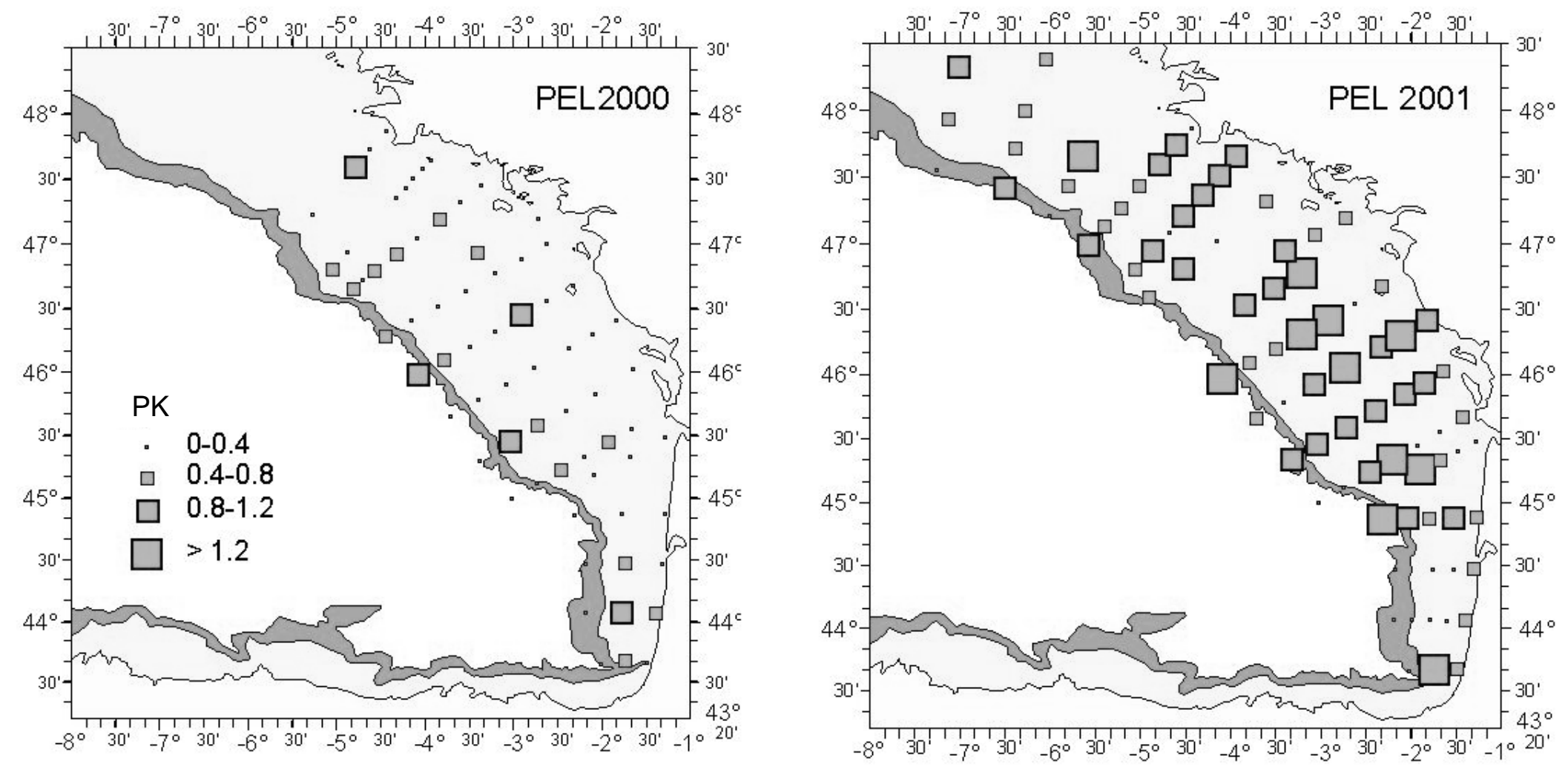

Fig 8

Spatial distributions of mesozooplankton PK specific activity ( $\mu \mathrm{M} \mathrm{NADH}$ oxidized $\mathrm{min}^{-1} \mathrm{mg}^{-1}$ protein) within the Bay of Biscay during spring periods of 2000 and 2001. 

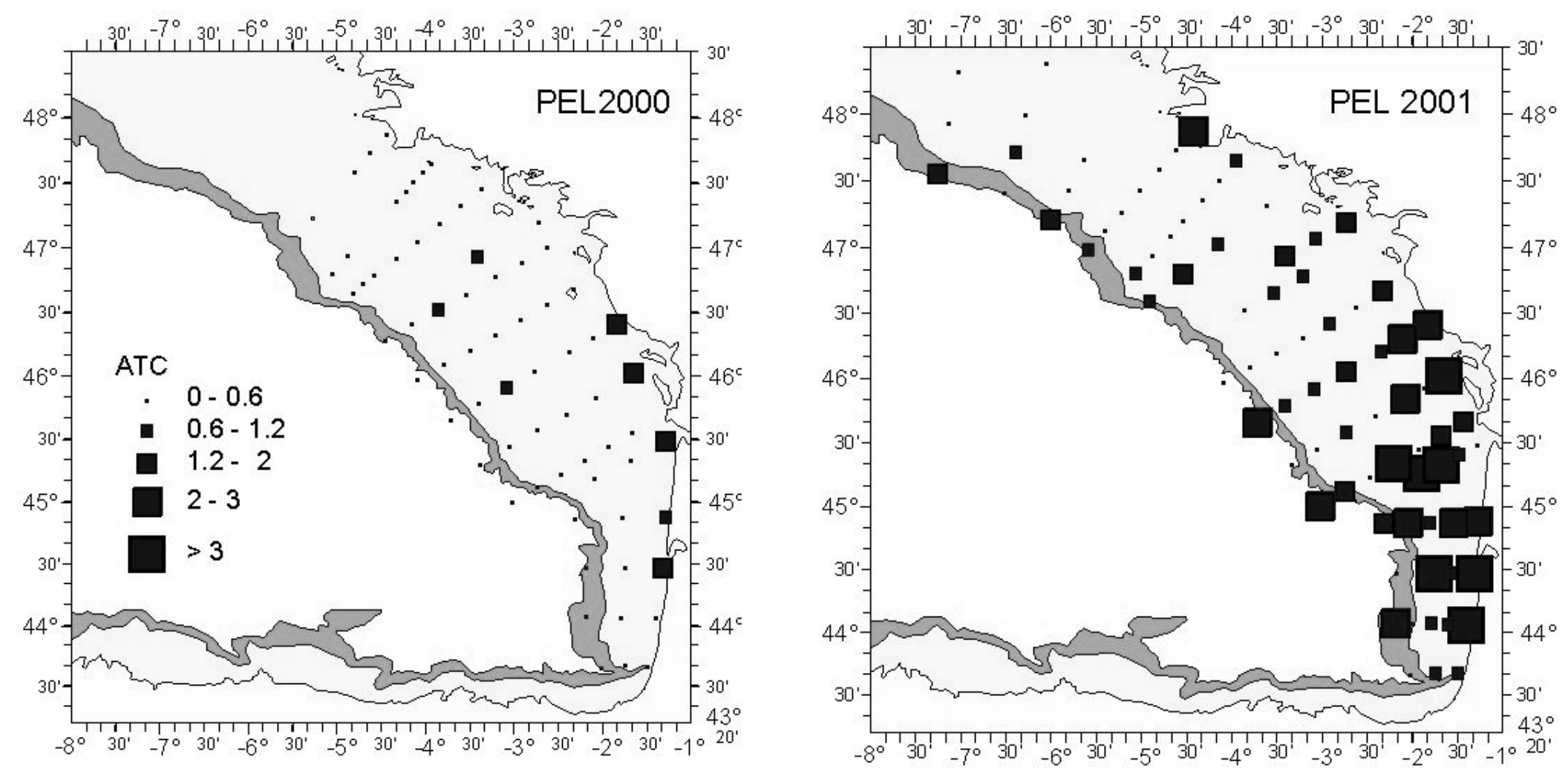

Fig 9

Spatial distributions of mesozooplankton ATC specific activity (nM CA (carbamylaspartate) produced $\mathrm{min}^{-1} \mathrm{mg}^{-1}$ protein) within the Bay of Biscay during spring periods of 2000 and 2001. 

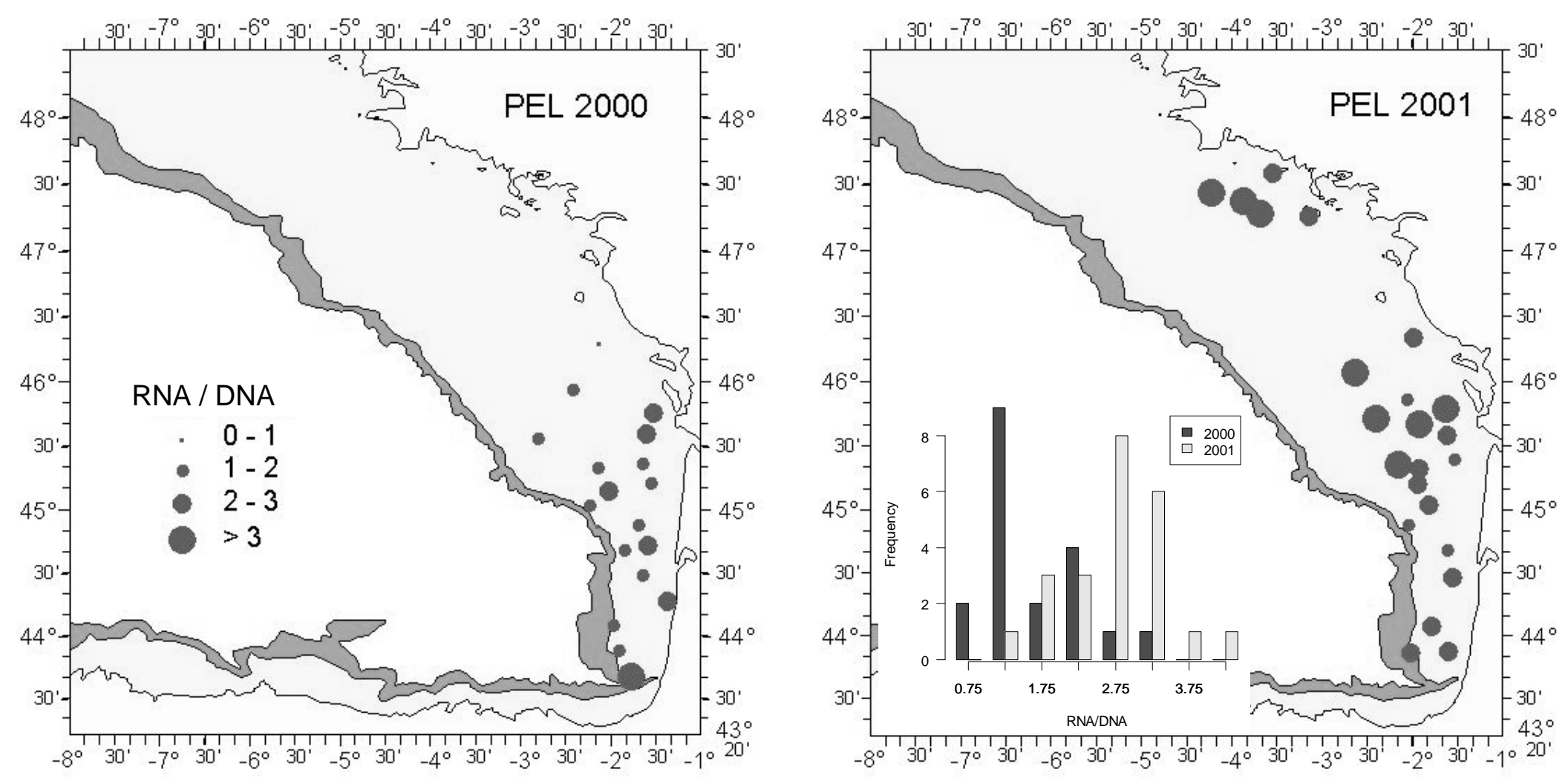
Fig.10

Inter-annual and spatial distribution of anchovy nutritional state. On the bottom left corner of the 2001 chart is presented the result of Pearson's chi-squared test for difference in distribution between both years: $p$-value $=0.0003$, which means that distributions are significantly different. 